\title{
Maxillary chondrosarcoma mimicking torus palatinus
}

\author{
Marina Brimioulle, Philippe Frederick Bowles, Andrew Pelser
}

ENT Department, Brighton and Sussex University Hospitals NHS Trust, Brighton, UK

\section{Correspondence to} Dr Marina Brimioulle, marina.brimioulle@gmail.com

Accepted 30 November 2017

\section{DESCRIPTION}

An 88-year-old man was referred to the head and neck surgery clinic for investigation of a painless hard palate lesion. The mass had been present for several months and was identified incidentally by the general practitioner. There were no oral or sinonasal symptoms. On examination, a $3 \times 2 \mathrm{~cm}$ hard palatal swelling, covered by normal mucosa and resembling a torus palatinus was identified (figure 1). Flexible nasal endoscopy revealed the tumour to involve the floor of the nasal cavity bilaterally, displacing the inferior nasal turbinates. Examination of the neck was normal.

A biopsy was taken, and histological analysis described a welldifferentiated cartilaginous lesion consistent with a grade 1 chondrosarcoma. A CT scan was performed (figure 2). The regional head and neck and regional sarcoma multidisciplinary team meetings recommended surgical management. The patient underwent a partial central maxillectomy via a combined approach (transoral and lateral rhinotomy). The palatal defect was temporarily obturated with a silicon putty, which was replaced by a permanent obturator 9 days later. The patient made a good recovery, and remains well with full speech and swallow 8 months postoperatively.

The resemblance of this lesion to a torus palatinus was striking. Similarly to tori, this lesion appeared in adult life and was painless. ${ }^{1}$ However, whereas tori

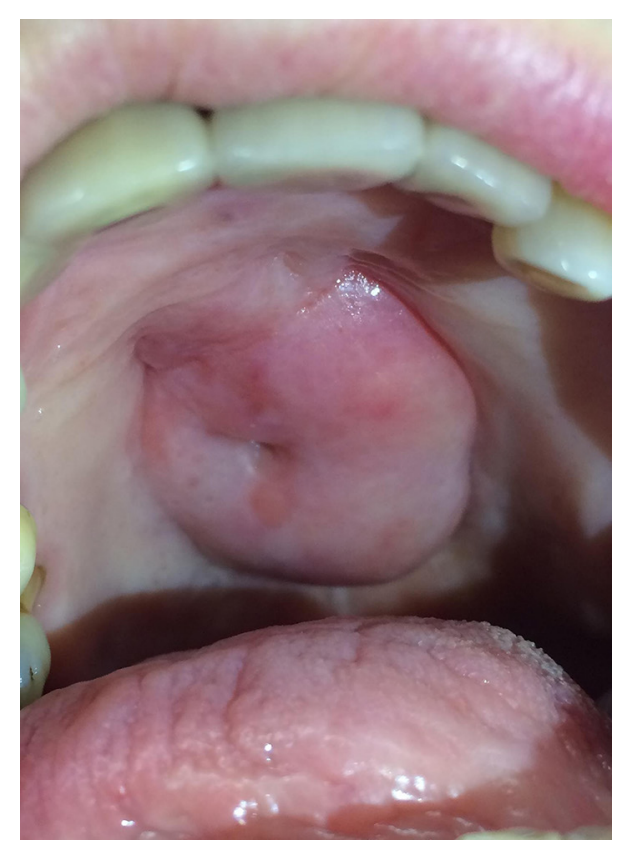

Figure 1 Midline palatal swelling covered by mucosa.

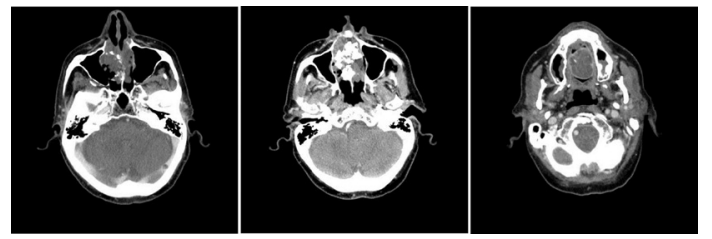

Figure 2 CT scan of the head and sinuses - axial views. The scan shows a $52 \times 43 \times 36 \mathrm{~mm}$ mass of mixed density. Inferiorly, the mass breaches the hard palate to enter the oral cavity. Superiorly, it extends up to the ethmoid air cells. Laterally, it extends to the medial walls of the maxillary sinuses. Posteriorly, it extends to the junction of the hard and soft palates.

\section{Learning points}

- Maxillary chondrosarcomas are rare lesions that can present similarly to the more prevalent tori palatini, and can therefore easily be mistaken for tori.

- Whereas tori palatini are benign lesions, maxillary chondrosarcomas are malignant and require surgical management in most instances.

- New suspicious head and neck lesions should be assessed by a specialist head and neck surgeon to ensure timely diagnosis of malignant lesions, and opportunity for curative treatment.

are common benign lesions, chondrosarcomas are rare malignant lesions, which may be locally destructive and metastasise. ${ }^{1-3}$ Chondrosarcomas are best managed surgically, with radiotherapy being used for advanced lesions..$^{2}$ Prompt diagnosis is important, in order to allow for curative surgical management.

Contributors $M B$ is the primary author of the manuscript. PFB and AP reviewed the manuscript.

Competing interests None declared.

Patient consent Obtained.

Provenance and peer review Not commissioned; externally peer reviewed.

(C) BMJ Publishing Group Ltd (unless otherwise stated in the text of the article) 2017. All rights reserved. No commercial use is permitted unless otherwise expressly granted.

\section{REFERENCES}

1 García-García AS, Martínez-González JM, Gómez-Font R, et al. Current status of the torus palatinus and torus mandibularis. Med Oral Patol Oral Cir Bucal 2010;15:e353-e360.

2 Coca-Pelaz A, Rodrigo JP, Triantafyllou A, et al. Chondrosarcomas of the head and neck. Eur Arch Otorhinolaryngol 2014;271:2601-9.

3 Kim MJ, Cho KJ, Ayala AG, et al. Chondrosarcoma: with updates on molecular genetics. Sarcoma 2011;2011:1-15. 
Copyright 2017 BMJ Publishing Group. All rights reserved. For permission to reuse any of this content visit http://group.bmj.com/group/rights-licensing/permissions.

BMJ Case Report Fellows may re-use this article for personal use and teaching without any further permission.

Become a Fellow of BMJ Case Reports today and you can:

- Submit as many cases as you like

- Enjoy fast sympathetic peer review and rapid publication of accepted articles

Access all the published articles

- Re-use any of the published material for personal use and teaching without further permission

For information on Institutional Fellowships contact consortiasales@bmjgroup.com

Visit casereports.bmj.com for more articles like this and to become a Fellow 